\title{
6. 'These unoffending people': myth, history and the idea of Aboriginal resistance in David Collins' Account of the English Colony in New South Wales
}

\section{RACHEL STANDFIELD}

Until the development of the discipline of Aboriginal history in the 1970s, the accepted conclusion of most Australian historians in the twentieth century was that the country was settled peacefully with little resistance from Aboriginal people. The scholarship of Aboriginal history has analysed and complicated this notion of peaceful settlement right across the country and throughout the history of colonisation. In the recent historiography of the very beginning of white settlement, however, the first five years of British settlement around Port Jackson are largely depicted as 'peaceful', in contrast to later periods of settler violence on the frontier. Alan Atkinson has written of the 'spirit of reciprocity which existed between Black and White at the very beginning'. Inga Clendinnen depicted the first five years of white settlement as the time 'before cynicism set in'. ${ }^{2}$ Her conclusions have led Robert Manne to view the first years of settlement as 'perhaps the only time in colonial Australia when the British and the Aborigines lived together not on the basis of subordination but equality'. ${ }^{3}$ This time is seen not only as characterised by equality, but also as lacking conflict over land. Clendinnen believed that early administrators 'as yet had no awareness of possible conflict over land' ${ }^{4}$ Josephine Flood's recent monograph stated that the expansion of British settlement to the Hawkesbury region in the 1790s was 'Australia's first conflict over land'. ${ }^{5}$ Deirdre Coleman has described this as an 'increasing orthodoxy' where the first years of settlement

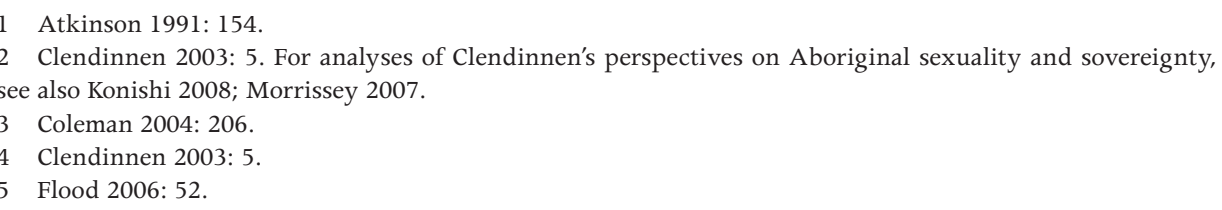


are seen as without conflict over land. The absence of land conflict fits with a more general theme in the historiography that the initial period of settlement was 'more innocent, more enlightened, less racist' than later colonial times. ${ }^{6}$

There are perhaps a number of reasons for this tendency to see early British settlement as without conflict. Some of these recent histories may be the product of their particular time in contemporary politics. Clendinnen, for example, expressed her hope that by examining British attempts to understand a different culture she was furthering 'social justice' between Indigenous and non-Indigenous Australians. ${ }^{7}$ This depiction of first settlement also, I would suggest, rests on insufficient analysis of the journals of the British officers, and in particular their discourses of class and race. One exception is Thomas Keneally's The Commonwealth of Thieves, whose analysis of the representations of convicts and Aboriginal people in the First Fleet journals is more nuanced than some other recent readings. ${ }^{8}$ This chapter also seeks to analyse the portrayal of convicts, to demonstrate how discourses of class impacted on the portrayal of relations between the British and Aboriginal people, shaping the representation of Aboriginal people as peaceful and unoffending.

This essay offers a detailed analysis of one publication by an officer of the First Fleet, that written by the first Judge-Advocate of the New South Wales colony, and secretary to Governor Phillip, David Collins. Collins published his Account of the English Colony in New South Wales in two volumes in 1798 and 1802. ${ }^{9}$ The author's central roles in the administration mean, as Alan Atkinson has pointed out, that his work 'echoed the original spirit of the state' and he was 'Australia's original historian'. ${ }^{10}$ The Eora occupied a position of particular importance in Collins' Account, with several chapters discussing ongoing relations between the locals and the newcomers, and a separate ethnology being included in the publication. Interrogating British representation of Indigenous resistance in a text such as this is important because it is closely linked to the colonial history of the country and the denial of Aboriginal sovereignty and land rights.

\section{Collins and Aboriginal resistance}

In the Account's first mention of encounter with Aboriginal people, Collins initiated a complex discourse combining a record of Aboriginal displeasure, a suggestion that the people were peaceful, and also an expression of concern

6 Coleman 2004: 206, 201. Evans 1999 outlines the potential role of conflict studies in Australian history writing and Broome 2005 provides a more nuanced and complex reading of violence in the first settlement of Victoria.

7 Clendinnen 2003: 5

8 Keneally 2005.

9 Collins 1798, 1802. For details of Collins' colonial career, see Currey 2000.

10 Atkinson 1991: 172, 91 . 
about the impact of colonisation on the Indigenous population. Collins first mentioned Aboriginal people while describing an exploration party, headed by Phillip and including Collins, travelling north along the coast from Botany Bay searching for a site for permanent settlement:

Their little fleet attracted the attention of several parties of the natives, who all greeted them in the same words, and in the same tone of vociferation, shouting every where 'Warra, warra, warra', words which, by the gestures which accompanied them, could not be interpreted into invitations to land, or expressions of welcome. ${ }^{11}$

Collins thus acknowledged Aboriginal resistance to the British but by combining it with description of the British party as a 'little fleet' downplayed any sense of threat to the locals. Aboriginal people in turn were characterised as peaceful and accommodating, Collins stating that in a previous encounter with the Botany Bay people they did not view the British 'as enemies or invaders of the country and their tranquillity'.$^{12} \mathrm{He}$ did, however, add in a crucial footnote to his conclusion that the British were not seen as invaders: 'How grateful to every feeling of humanity, would it be that we could conclude this narrative without being compelled to say, that these unoffending people had found reasons to change both their opinions and their conduct'. ${ }^{13}$ This footnote appeared to question whether the Port Jackson settlement was as peaceful as the British had hoped and to reflect on the disturbance it had caused the Eora. ${ }^{14}$ Crucially, however, in its use of the term 'unoffending' Collins also characterised Aboriginal people as of no threat to the colony. Nicholas Thomas has stated that Collins saw the Indigenous population as 'both essentially benevolent and fatally unknowing' even while he writes about their 'belligerence', concluding that Collins 'never makes resistance a theme' ${ }^{15}$

Thomas is right; Collins did not make resistance a theme. In this tendency he was following those British travellers who had been before him. In fact, one of the reasons Australia was chosen as the site for convict settlement was because resistance from Aboriginal people was not expected. Certainly in evidence to the Committee of Transportation meeting to consider a convict settlement in 1779 and 1785, Joseph Banks, the most influential British person to have encountered Aboriginal people, highlighted their supposed lack of resistance. While encounters with Aboriginal people had been fleeting and marked by a lack of common language, Banks did not hesitate to use his impressions as

11 Collins 1798: 3.

12 Collins 1798: 3.

13 Collins 1798: 3.

14 Deirdre Coleman has identified moments where the 'dispossessing intruders register both triumph and uneasiness' as a theme of discourses of 'romantic colonization'. Coleman 2005: 14.

15 Thomas 1999: 35. 
evidence to the Committee. On both of the occasions he testified before the Committee Banks advocated Botany Bay as his preferred site for settlement. In 1779 he stated that based on his experience of New South Wales in 1770 there was 'little probability of any opposition' from the Indigenous population. He had seen very few people at Botany Bay and assumed the country was 'thinly peopled'. Central to his evidence was an imagined colonial scenario marked by a lack of Aboriginal resistance; he thought the people armed and 'treacherous' but cowardly because they avoided confronting the voyagers. ${ }^{16}$ When Banks testified again in 1785, the Committee asked about Aboriginal defensive capacity and weaponry as well as whether land could be ceded or sold. Banks believed land could not be sold, because while the Endeavour had been in Australia 'there was nothing we could offer that they would take' except food. ${ }^{17}$ Banks repeated his comments from six years before, that there were few Aboriginal inhabitants, who looked 'inclined to Hostilities' but 'did not appear at all to be feared'. ${ }^{18}$ When the Committee asked whether the Indigenous inhabitants would obstruct a party of colonists and prevent their settlement, Banks answered emphatically 'Certainly not'; his experience led him to believe 'they would speedily abandon the Country to the New Comers'. ${ }^{19}$

Assumptions of a sparsely populated and undefended country, developed out of the Endeavour voyage and reiterated by Banks, had major consequences. They meant that Phillip's instructions did not compel him to negotiate for settlement. His instructions did, however, direct him to collect further information about Aboriginal people, to

endeavour to procure an account of the number inhabiting the neighbourhood of the intended settlement, and report your opinion to one of our Secretaries of State in what manner our intercourse with these people may be turned to the advantage of this colony. ${ }^{20}$

Merete Borch has argued that these instructions allowed scope for a policy change towards Aboriginal people once settlement had started. She concluded that if colonial officials had recommended a treaty, the metropolitan government would have negotiated with Aboriginal people. Borch remained puzzled, however, by the continued lack of negotiation as knowledge increased about Aboriginal people and 'their hostility towards settlement on their land was being clearly displayed' ${ }^{21}$ The issue here, then, becomes one of whether British observers really did think Aboriginal people were hostile to the British settlement.

16 Quoted in Borch 2004: 86

17 King 1985: 55-56.

18 King 1985: 54-55.

19 King 1985: 60-61.

20 Quoted in Borch 2004: 79.

21 Quoted in Borch 2004: 104. 
Governor Phillip's thoughts about resistance were implicit in his plans for the new colony, set out in his 'Conduct of the Expedition and the Treatment of Convicts' in $1787 .{ }^{22}$ While Phillip believed the Aboriginal population might be larger than the numbers that Cook had seen, he saw need only for 'throwing up a slight work as a defence' against them. Endeavouring to establish the colony without any disputes with Aboriginal people, Phillip planned to completely separate the convicts and ships' crews from interacting with Aboriginal people, fearing that convicts and crew would come to possess Aboriginal weapons, that Aboriginal women would be mistreated and 'the natives disgusted' ${ }^{23}$ Phillip may not have seen Aboriginal people as a threat, but he thought Māori the best deterrent for the crimes of murder and sodomy. He planned to send offenders to 'the natives of New Zealand, and let them eat him'.$^{24}$ As Raymond Evans and Bill Thorpe have explained, the convict system rested on the construction of convicts as a 'criminal class' creating a presumption that convicts were always at fault. ${ }^{25}$ Penny Russell has stated that convicts and other undesirable groups were used as 'scapegoats' within the colonising project, and so they would come to be in the Account. ${ }^{26}$

In understanding British perceptions of Aboriginal responses to the British settlement, David Collins's Account takes on a very important role in the production of knowledge about Aboriginal resistance and in the shaping of British policies towards the Indigenous population. From the very beginning of his description of encounters between the British and the Eora, there were Eora attacks he could have described as resistance, but the presence of the convict population meant that he did not have to contemplate them as such. Collins would consistently blame convicts for Aboriginal attack, and in doing so he maintained his representation of Aboriginal people as unoffending, without the agency necessary to resist the colonisation of their country.

In March 1788, convicts began to be speared as they left the confines of the settlement; one was 'dangerously wounded with a spear, the others very much beaten and bruised by the natives' ${ }^{27}$ The explanation Collins provided for the initial attack would be repeated on numerous occasions over the coming months - while the convicts denied provoking Aboriginal people the Judge-Advocate did not believe them. ${ }^{28}$ In May 1788 one convict was wounded and another killed when they 'strayed' beyond the settlement, and two other convicts were killed when cutting rushes, having been 'pierced through in many places

\footnotetext{
Phillip 1892[1787]: 50-54.

Phillip 1892[1787]: 52.

Phillip 1892[1787]: 53.

Evans and Thorpe 1998: 17.

Russell 2005: 36.

Collins 1798: 23.

Collins 1798: 24 .
} 
with spears, and the head of one beaten to a jelly'. ${ }^{29}$ Collins' reporting of such incidents began to form a pattern whereby convicts were said to be 'offending' Aboriginal people and 'straggling', with violent encounters being repeatedly conceptualised as isolated occurrences rather than being seen as reflective of ongoing hostility towards the settlement. Even as violence escalated Collins did not perceive that Aboriginal people may have been retaliating against the British presence on their land or attacking the colony itself. In response to the death of the rush-cutters Phillip sent out an armed party to find the offenders. This initiated Phillip's strategy of reprisals if those hurt were working for the support of the colony, and especially if they were gathering food. The Governor, attempting to find and 'secure' those who killed the men, sent out 'a strong party well armed'.$^{30}$ Phillip could not find the offenders - although how he would have known them if he met with them is unclear - but instead encountered a group of two to three hundred Aboriginal people. They had a 'friendly' meeting, perhaps due to the overwhelming weight of Aboriginal numbers, and exchanged spears for hatchets.

With dwindling fishing stocks in the winter of 1788 Collins reported that the Eora 'appeared to be in great want' ${ }^{31}$ They confronted a British fishing party and took half the catch in an attack described as showing strategy and marking a change from the previous Eora approach of waiting to be given fish. ${ }^{32}$ It was impossible for the British to tell if the Aborigines were 'driven by hunger, or motivated by some other cause', but they sent an armed officer on subsequent fishing trips. ${ }^{33}$ During June and July there were more violent incidents but also more friendly interaction between convicts and Aborigines. Some groups were hostile but others were friendly:

In one of the adjoining coves resided a family of them, who were visited by large parties of the convicts of both sexes on those days in which they were not wanted for labour, where they danced and sung with apparent good humour, and received such presents as they could afford to make them; but none of them would venture back with their visitors. ${ }^{34}$

Thus, in the initial months a complex relationship was developing between the colonists and the Indigenous people of the Sydney region. While Collins always blamed the convicts for provoking Aboriginal people, we cannot discount the possibility that convicts were deliberately targeted as they moved about alone

29 Collins 1798: 30.

30 Collins 1798: 31.

31 Collins 1798: 31.

32 Collins 1798: 31.

33 Collins 1798: 31. Raymond Evans has written about similar Aboriginal reactions to another large British settlement (that of the Moreton Bay convict settlement from 1824) and he has argued that the Nunukul people's forcible seizure of crops can be seen from the perspective of extracting 'land rents'. Evans 1999: 60. 34 Collins 1798: 37. 
and unarmed, and travelled with difficulty in an alien landscape. In another respect the Aboriginal strategy of targeting convicts away from the settlement suited the British officers as it helped to control the population of prisoners. In effect the Eora became a police force, patrolling the boundaries of the open-air prison that was the new colony, and making it easier for the administration to keep the prisoners physically confined. Along with the violent confrontation, however, there was at least one friendly meeting, an unusual description that alerts us to silences within the text. Collins was concerned to record the administrative detail of the colony and to document breaches of the law in his role as Judge-Advocate, and as such the Account does not generally document the daily life of the convicts outside of the interest of the colonial administrators; it could not document the daily lives of the Eora. ${ }^{35}$

In October Collins reported the death of another convict 'who had been looked upon as a good man'. He had accompanied an armed party to gather food but was killed when he left the group: 'his head beat to a jelly, a spear driven through it, another through his body, and one arm broken' ${ }^{36}$ The concept that Aboriginal people were unoffending, however, framed Collins' discourse such that episodes of resistance did not change his ideas. His refusal to consider that the Eora might defend what had been, less than a year earlier, their home, resulted in a simplistic narrative that split the colonists between officers displaying goodwill and convicts filled with vice. Despite this discourse, however, the colonial approach to relations with the Eora was changing in significant ways. Phillip shifted his approach from management of the convicts, by government order and threat, to trying to directly manage the Eora. His strategies reflect the normalisation of violence within administrative practices in penal and colonial situations. With the next Aboriginal attack, an attempted spearing of another convict, Phillip sent out the military to retaliate, to force Aboriginal people away from the white settlement. ${ }^{37}$ The strategy had shifted from original encouragement of friendly relations with the Eora, to making an armed show of strength to keep the Indigenous population from the edge of the settlement.

By December 1788 the colonial authorities had settled on kidnapping to manage the Eora, as they 'were becoming every day more troublesome and hostile'. Kidnapping would allow the British to learn the local language so that the Indigenous population 'might learn to distinguish friends from enemies', and in December 1788 Arabanoo, a Cammeraygal man, was captured. ${ }^{38}$ Arabanoo's

35 Laugeson 2002. Laugeson has described how commentators noted the English spoken by Aboriginal people reflected convict slang. This sort of evidence demonstrates that even though Phillip had wanted complete separation between convicts and Aborigines, and the Collins Account was often silent on interaction between convicts and Aborigines, complete separation was outside of the control of the administration.

36 Collins 1798: 43.

37 Collins 1798: 44-45.

38 Collins 1798: 49. 
kidnapping did not stop the strikes at the periphery of the colony. Collins' report of another Eora attack on a party of rush cutters early in 1789 provides us with an insight into the other reasons that may have been behind Arabanoo's capture. Collins wrote that the Aboriginal people had attacked the British

notwithstanding they must have known at that time we had one of their people in our possession, on whom the injury might have been retaliated. He, poor fellow, did not seem to expect any such treatment from us, and began to seem reconciled to his situation. He was taken down the harbour once or twice, to let his friends see that he was alive, and had some intercourse with them which appeared to give him much satisfaction. ${ }^{39}$

As well as the desire to learn language and prove the colonisers' 'friendly' intentions, the British tactic of kidnapping can also be seen from the perspective of hostage taking to prevent attacks against the settlement. To view kidnapping in this light is to take seriously British concern about Eora resistance, and belies the simplistic conclusion that Aboriginal people were unoffending.

Collins was belatedly realising that Phillip's original plan to keep the convicts segregated from the Indigenous population would not work, as the 'impracticability' of the scheme, he wrote, 'became every day more evident' ${ }^{40}$ Collins stressed that government orders to avoid leaving the settlement had been devised for the good of convicts, but they ignored them, as they were not 'thinking beings' ${ }^{41}$ When a convict was killed collecting vegetables at Botany Bay, 16 men from his brick-making work gang went in search of revenge, armed with wooden stakes. ${ }^{42}$ They met with and were repelled by a group of about 50 Eora, who killed another man and wounded six more. The Governor's response was to attempt to regulate the Aboriginal and convict violence by using statesanctioned punishment and military power in response. Lawrence Stone has concluded that the role of the British military state during this period was 'monopolizing as much as possible of legitimate violence', and Phillip's actions in this instance display this imperative for state control of violent acts. ${ }^{43} \mathrm{He}$ sent an armed party to Botany Bay to collect the bodies. He ordered all of the convict revenge party to receive 150 lashes and wear a leg iron for a year. In addition he launched a military patrol around the settlement to warn the Eora, with two groups of soldiers sent, 'one toward Botany Bay, and the other in 
a different direction, that the natives might see that their late act of violence would neither intimidate nor prevent us from moving beyond the settlement whenever occasion required'. ${ }^{44}$

Arabanoo's death in the smallpox epidemic that ravaged his people in May 1789 gave Phillip a 'determination to procure another [captive] at the first favourable opportunity' and two men were captured in November 1789. ${ }^{45}$ Colebe, a Cadagal man, only stayed a few days before escaping, but Bennelong, a Wahngal man, was thwarted in his attempt to escape with Colebe, and lived in the Port Jackson settlement until his eventual escape in May 1790. In the edited collection of Phillip's despatches, the first British publication on the New South Wales colony, the kidnapping was characterised as 'the kindest piece of violence that could be used'. ${ }^{46}$ Coleman has read this phrase as epitomising the 'chivalric discourse' which masks 'dominion as kindness, gallantry and good intentions whilst bolstering the intruders' sense of their own superiority' ${ }^{47}$ This chivalric discourse is, she has suggested, 'seductive', as it allows the characterisation of Australian colonial beginnings as 'somehow pristine, a period of genuine curiosity and friendly overtures, untainted by the frontier racial violence which was to follow in the nineteenth century' ${ }^{48}$ Perhaps also seduced by this chivalric discourse, Clendinnen uncritically reproduced Lieutenant William Bradley's description of the kidnapping which he was ordered to carry out. Describing it as 'by far the most unpleasant service I was ever ordered to execute', Bradley recounted the way he lured Bennelong and Colebe with gifts of fish before hauling them into the boat. ${ }^{49}$ Rather than focus on the British use of kidnapping, Clendinnen has wondered 'what possessed' the Indigenous men 'to wade out to a British boat'? She did not consider the Eora's distress for want of food, their previous shows of resistance at British refusals to share fish, or their attempts to extend their ideas of obligation and reciprocity to the Europeans who were living on their land. Instead, Clendinnen speculated that they came towards the boat to allow Bradley to kidnap them because the two men were playing a 'game of dare'. While Clendinnen stressed that she was not suggesting 'they wanted to be captured', she nevertheless characterised the kidnapping as a case of 'competitive daring that went wrong' for the Indigenous men. ${ }^{50}$ Theatricality and gamesmanship have replaced coercion in this reading, which has been divorced from the operation of state power and the serious business of colonial management of Indigenous peoples in order to undertake the colonisation of their lands.

44 Collins 1798: 58.

45 Collins 1798: 86.

46 Phillip 1789: 79, quoted in Coleman 2005: 165.

47 Phillip 1789: 79, quoted in Coleman 2005: 165.

48 Phillip 1789: 79, quoted in Coleman 2005: 165-166.

49 Quoted in Clendinnen 2003: 105.

50 Quoted in Clendinnen 2003: 106. 
Neither the kidnapping of Bennelong, however, nor his eventual return to his people and ongoing relationship with the British, stopped conflict. Perhaps the most serious of the attacks, for both the Aboriginal population and for the British, was the spearing of the convict gamekeeper McIntyre in December $1790 .{ }^{51}$ McIntyre was suspected of cruelty towards Aborigines, and he was speared at a time when the colony was on the brink of starvation. Phillip mounted another armed party in retaliation, and charged the military to return to the settlement with the heads of ten Aboriginal men. ${ }^{52}$ When the first reprisal raid was unsuccessful, with the soldiers unable to find any trace of Indigenous people, Phillip sent them out again. It seems clear that the failure of the soldiers to take revenge was more to do with their own lack of knowledge of Eora country than for want of trying. Clendinnen has claimed that the expedition was Phillip's attempt to 'protect' Aboriginal people from the 'racist terror' of other British settlers, which would 'come soon enough'. ${ }^{53}$

The attack on McIntyre was of such seriousness that Collins admitted for the first time in his Account that Aboriginal attacks might be about land, stating that:

we had not yet been able to reconcile the natives to the deprivation of those parts of this harbour which we occupied. While they entertained the idea of our having dispossessed them of their residences, they must always consider us as enemies, and upon this principle they made a point of attacking the white people whenever opportunity and safety concurred. ${ }^{54}$

This is a crucial admission, but it is one that is not seriously considered within the synthetic ethnological assessment of Aboriginal society that Collins included in his Account. In one key part of this ethnology, the section dealing with property, we can see Bennelong's attempts to explain his relationship to country to the British, and view the way the British reacted to such information. Collins devoted only one paragraph to Bennelong's explanation of Aboriginal property ownership. This is the passage in full:

Their spears and shields, their clubs and lines, \&c. are their own property, they are manufactured by themselves, and are the whole of their personal estate. But, strange as it may appear, they have also their real estates. Ben-nil-long, both before he went to England and since his return, often assured me, that the island Me-mel (called by us Goat

\footnotetext{
51 Collins 1798: 143.

52 Collins 1798: 143-144.

53 Clendinnen 2003: 181. Coleman has dismissed this conclusion as 'nothing less than wishful thinking, an implausible distortion of the record', Coleman 2004: 208.

54 Collins 1798: 147.
} 
Island) close by the Sydney Cove was his own property; that it was his fathers', and that he should give it to By-gone, his particular friend and companion. To this little spot he appeared much attached, and we have often found him and his wife Bar-rang-a-roo feasting and enjoying themselves on it. He told us of other people who possessed this kind of hereditary property, which they retained undisturbed. ${ }^{55}$

While Collins was prepared to admit a sense of personal ownership of goods, he had more trouble explaining, or admitting to, Aboriginal ownership of land. He stated that Aboriginal people believed they owned land, 'strange as it may appear', given the British assumption that there was no concept of land ownership in Aboriginal society, and that Aboriginal people lived in a 'state of nature'. Giving authority to Bennelong's assertion of his own, as well as other people's, attachment to and ownership of particular areas of land was a move which could threaten to undermine a tenet of European thought on the basis of which the colony of New South Wales had been founded. ${ }^{56}$ Bennelong's assertion of his continued connection to country and maintenance of his relationship to land attest to the other forms of resistance utilised by Aboriginal people and their maintenance of culture in the face of the colonisation of their land. As Frances Peters-Little has described: 'Aboriginal people were constantly resisting and maintaining "Aboriginality" even though the dominant view of resistance was generally limited to understanding "resistance" only in terms of violence on the frontier' ${ }^{57}$

Thus, no matter what Bennelong told the British about his peoples' relationship to country, and no matter how the Eora retaliated against the British, Collins did not attempt to assimilate this new information into his assumptions about the level of advancement of Aboriginal society. Collins described Aboriginal people as having only the most rudimentary form of social development; the preface to the Account spoke of the rare occurrence of establishing a colony in the most remote part of the habitable globe; it is seldom that men are found living in a state of nature'.$^{58}$ The idea that the Eora lived in a state of nature was reiterated at the beginning of the ethnological section of the Account:

We found the natives about Botany Bay, Port Jackson, and Broken Bay, living in that state of nature which must have been common to all

55 Collins 1798: 598-599.

56 For a description of individual relations to particular areas of country in Aboriginal culture, see Goodall 1996: 9.

57 Peters-Little 2005.

58 Collins 1798: ix. 
men previous to their uniting in society, and acknowledging but one authority. These people are distributed into families, the head or senior of which exacts compliance from the rest. ${ }^{59}$

Robert Dixson has concluded that Collins' work owed a large debt to Lord Monboddo's of the Origin and Progress of Language. ${ }^{60}$ In particular, Dixson concluded that, while Collins did not place Aboriginal people in the very lowest state of humanity, believing them above a 'Brutish State' by virtue of their organisation into families, 'apparently in deference to Lord Monboddo, he continued to describe them as living in a "state of nature" ${ }^{\prime \prime} .{ }^{61}$ This assessment of Indigenous society was also useful from the perspective of colonial endeavour, however, as it placed Aboriginal society at a level which did not have a conception of property ownership. In effect, it ignored Aboriginal peoples' own articulation of their property rights to reiterate the conclusions that Aboriginal people had no property rights which Cook had expressed, and which had formed the basis of the decision to settle without negotiation.

Merete Borch has suggested that the British government was open to new information about Aboriginal society, realising that the initial colonisation had been based on partial knowledge developed out of fleeting encounters. While it was difficult for Collins to admit, he eventually came to recognise that Aboriginal people had a sense of property rights in land, and that they resisted white settlement. Ten years after settlement was initiated, Collins' Account, with its reluctant story of Aboriginal resistance and one solitary paragraph on Indigenous property ownership, was published in England. By this time, however, British settlement was expanding apace, and the sceptical explanation of property rights was too little and came too late to change the form of the colonial project.

In addition, Collins' publication came to hold an influential place in the development of racial thought about Aboriginal people, thus ensuring that his views on both race and resistance became enshrined in dominant British understandings of Australian Indigenous people. The Account was used by natural scientists hungry to assimilate knowledge of newly discovered peoples into their theories of human difference. A report on Collins' work was published in the Edinburgh Review in 1803, attributed to Sydney Smith, which praised Collins as an author, stating that the 'book is written with great plainness and candour'. The reviewer felt the most important contribution of the Account was the discussion of Aboriginal people, their physical features and cultural characteristics. They supposedly had only a rudimentary knowledge of politics

59 Collins 1798: 544.

60 Burnet 1773-1792.

61 Dixson 1986: 24. 
and seemed 'to have scarcely advanced beyond family-government'. Their small population was caused by Aboriginal 'ferocity of manners' combined with the 'sterility of their country'. Smith concluded that Aboriginal people were 'extremely low, in point of civilization, when compared with many other savages, with whom the discoveries of Captain Cook have made us acquainted' ${ }^{62}$ The Account was also integral to the assessment of Aboriginal people offered by James Cowles Pritchard in 1813 in his highly influential Researches into the Physical History of Man, ${ }^{63}$ which became a 'landmark in British racial science' ${ }^{64}$ While Pritchard also used the accounts of European voyagers such as Dampier and Cook, he relied heavily on the work of Collins. ${ }^{65}$ Pritchard described Aboriginal people as the 'squalid companions of kangaroos', who 'may be seen crawling in imitation of quadrupeds', an unflattering description which he used in contrast to the spectacle of a European coronation ceremony and which was closely based on Collins' description of a 1795 corroboree which had included dances imitating kangaroos and dingoes. ${ }^{66}$

Thus, far from providing new knowledge which could form the basis of negotiation between Aboriginal people and the British, Collins' work reiterated ideas that Aboriginal people did not resist, and was used by metropolitan thinkers to argue that Aboriginal people were low on the hierarchy of humanity.

\section{Resistance in histories of the region}

The Account's descriptions of Māori, whom British colonists were also contacting at this time, demonstrate how an expectation of resistance could impact on British behaviour. Collins included as an appendix to the first volume of the Account a report from Phillip Gidley King, Lieutenant Governor of Norfolk Island, on his interaction with two North Island Māori men. King had ordered the men, Tuki and Huru from the Muriwhenua region in the north of the North Island, kidnapped and brought to the island to teach the convicts how to weave flax. He detained them on Norfolk Island from April to October 1793. New Zealand histories agree that kidnapping Tuki and Huru was an affront to Māori. ${ }^{67}$ Judith Binney has stated that 'the chiefs were insulted by the manner of their removal' ${ }^{68}$ Anne Salmond described the kidnapping 'as a strange way to create

62 Smith 1803: 34.

63 Pritchard 1973[1813]: 261-272.

64 Stepan 1982: 2.

65 Pritchard 1973[1813]: 265.

66 Quoted in Wheeler 2000: 293, and see Collins 1798: 566, 570.

67 Binney 2004; Salmond 1997.

68 Binney 2004: 15. 
an alliance', but she also implied that kidnapping was a prudent British policy, and that Mâori naturally displayed caution towards the visitors, because of the history of violent contact between Māori and Europeans in the region. ${ }^{69}$

While Tuki and Huru's kidnapping led to the collection of ethnographic information, as did the kidnapping of Arabanoo, Bennelong and Colebe, the information provided by the Māori captives was received and reproduced in a very different manner. Firstly, Tuki and Huru were understood to occupy important places in a hierarchical Māori society. Huru was described as a warrior and Tuki a priest, with the men proving to have no knowledge of making flax, as women undertook this task. ${ }^{70}$ Huru's status as a warrior confirmed for the British their understandings of Māori as a 'warrior race', formed on Cook's Pacific voyages. ${ }^{71}$ Tuki further entrenched this idea when he drew for the British a map, reproduced in the Account, which demarcated tribal regions governed by their respective chiefs and included details of the number of warriors belonging to each place. North Island people were said to be in a 'constant state of warfare with other tribes', but during times of peace traded for flax and greenstone. ${ }^{72}$ The map also included the 'immense pine trees' growing near the Hokianga River, which became the basis of a later trade in timber by New South Wales merchants. ${ }^{73}$ The map not only sparked interest in a trading relationship with Māori, but it also entrenched ideas that Māori had property rights, and that chiefs owned land which they defended with warriors. ${ }^{74}$ The British imagined an imperial relationship, but did not consider colonisation. The authority accorded to Tuki's map in the Account legitimised Māori perspectives of their own society within European ethnology, and differed markedly from the one sceptical paragraph Collins devoted to Aboriginal ideas of their land ownership.

Māori resistance, be it actual physical resistance or the threat of it, is taken for granted in New Zealand historiography, for example in the works of Judith Binney and Anne Salmond, and is seen as shaping British actions in their encounters with Māori. New Zealand historians assume what Australian historians at times do not, that the Indigenous population resisted the imperial power that intervened in their country. In doing so they also reiterate the perspectives of early British observers who, representing Māori as a warrior race, always expected Indigenous peoples in New Zealand to resist them. As Michael King concluded:

\footnotetext{
69 Salmond 1997: 209.

70 Collins 1798: 521.

71 Standfield 2008.

72 Collins 1798: 522.

73 Salmond 1997: 16.

74 Salmond 1997: 524-525.
} 
Australian Aboriginal people were assumed to be less martial than Maori, less organised and vigorous, and therefore easier to control in the operation of a colonial enterprise. This decision protected Maori from a concerted attempt at foreign colonisation of New Zealand for a further 50 years and gave them time to better adjust to the implications... ${ }^{75}$

Dialogue with New Zealand histories can encourage Australian historians to question British assumptions about Aboriginal people, especially one so intertwined with racial thought and the lack of recognition of sovereignty as the notion that Aboriginal people did not resist the settlement at Port Jackson. This idea was so powerful at the time that it continued to be expressed no matter how the Eora reacted to the British, and it has proved so enduring since as to resurface in our current reflections on early white settlement. Engaging with these regional histories can serve to remind Australian historians that British travellers and colonists made their early observations of indigenous peoples in the light of prevailing discourses of race and class, as well as that of British imperial ambition.

\section{References}

Atkinson, Alan 1991, The Europeans in Australia: A History, vol 1, The Beginning, Oxford University Press, Oxford.

Binney, Judith 2004, 'Tuki's universe', New Zealand Journal of History 38(2): 215-232.

Borch, Merete Falck 2004, Conciliation - Compulsion - Conversion: British Attitudes Towards Indigenous Peoples, 1763-1814, Rodopi, Amsterdam and New York.

Broome, Richard 2005, Aboriginal Victorians: A History since 1800, Allen \& Unwin, Crows Nest, New South Wales.

Burnet, James, Lord Monboddo 1773-1792, Of the Origin and Progress of Language, 6 vols, A Kincaid and W Creech, T Cadell, Edinburgh and London.

Clendinnen, Inga 2003, Dancing with Strangers, Text Publishing, Melbourne.

Coleman, Deirdre 2004, 'Inscrutable history or incurable romanticism? Review of Inga Clendinnen's Dancing with Strangers', Heat 8: 201-213.

- 2005, Romantic Colonization and British Anti-Slavery, Cambridge University Press, Cambridge.

75 King 2003: 114. 
Collins, David, 1798 and 1802, An Account of the English Colony in New South Wales, with remarks on the dispositions, customs, manners, \&c., of the native inhabitants of that country. To which are added some particulars of New Zealand. Compiled by permission, from the MSS of Lieutenant-Governor King, by David Collins Esquire, Late Judge-Advocate and Secretary of the Colony, Illustrated by Engravings, T Cadell, jun and W Davies, London.

Currey, John 2000, David Collins: A Colonial Life, Miegunyah Press and Melbourne University Press, Carlton South.

Dixson, Robert 1986, The Course of Empire: Neo-Classical Culture in New South Wales, 1788, 1860, Oxford University Press, Melbourne.

Evans, Raymond 1995, 'Blood dries quickly: conflict study and Australian historiography', Australian Journal of Politics and History 41(special issue): 80-102.

- 1999, 'The Mogwi take Mi-an-jin: race relations and the Moreton Bay penal settlement, 1824-1842', in Fighting Words: Writing about Race, Raymond Evans (ed), University of Queensland Press, St Lucia: 48-79.

- and Bill Thorpe 1988, 'Commanding men: masculinities and the convict system', Journal of Australian Studies 56: 17-34.

Flood, Josephine 2006, The Original Australians: Story of the Aboriginal People, Allen \& Unwin, Crows Nest, New South Wales.

Goodall, Heather 1996, Invasion to Embassy: Land in Aboriginal Politics in New South Wales, 1770-1972, Allen \& Unwin in association with Black Books, St Leonards, New South Wales.

Keneally, Thomas 2005, The Commonwealth of Thieves, Random House, Milsons Point, New South Wales.

King, Jonathan 1985, 'In the Beginning...': The Story of the Creation of Australia from the Original Writings, MacMillan, South Melbourne and Crows Nest.

King, Michael 2003, The Penguin History of New Zealand, Penguin, Auckland.

Konishi, Shino 2008, 'Wanton with plenty: questioning ethno-historical constructions of sexual savagery in Aboriginal societies, 1788-1803', Australian Historical Studies 39(3): 356-372.

Laugeson, Amanda 2002, 'The politics of language in colonial Australia, 17881850', Journal of Colonial History 4(1): 18-40. 
Morrissey, Phillip, 2007, 'Dancing with shadows: erasing Aboriginal self and sovereignty', in Sovereign Subjects: Indigenous Sovereignty Matters, Aileen Moreton-Robinson (ed), Allen \& Unwin, Crows Nest, New South Wales: 69-70.

Peters-Little, Frances 2005, 'An Aboriginal session on Gandhi's Indian Home Rule interview about history and passive resistance, 1909', Borderlands e-journal 4(3), accessed 15 May 2010: <http://www.borderlands.net.au/ vol4no3_2005/peters_session.htm>

Phillip, Arthur, 1892[1787], 'Phillip's views on the conduct of the Expedition and the Treatment of Convicts', reprinted in Historical Records of New South Wales, vol 1, part II, Charles Potter Government Printer, Sydney: 50-54.

-1789, The Voyage of Governor Phillip to Botany Bay; with an Account of the Establishment of the Colonies of Port Jackson and Norfolk Island, John Stockdale, London.

Pritchard, James Cowles 1973[1813], Researches into the Physical History of Man, reprinted with an introductory essay by George W Stocking Jnr, University of Chicago Press, Chicago and London.

Russell, Penny 2005, 'Unsettling settler society', in Australia's History: Themes and Debates, Martin Lyon and Penny Russell (ed), University of New South Wales Press, Sydney: 22-40.

Salmond, Anne 1997, Between Worlds: Early Exchanges between Maori and Europeans, 1773-1815, Viking Press, Auckland.

Smith, Sydney (attributed) 1803, 'Review of David Collins, An Account of the English Colony in New South Wales', Edinburgh Review 11: 3.

Standfield, Rachel 2008, 'Violence and the intimacy of imperial ethnography: the Endeavour in the Pacific' in Moving Subjects: Mobility, Intimacy and Gender in a Global Age of Empire, Antoinette Burton and Tony Ballantyne (eds), University of Illinois Press, Urbana and Chicago: 31-48.

Stepan, Nancy 1982, The Idea of Race in Science, 1800-1960, Macmillan Press, London and Basingstoke.

Stone, Lawrence 1994, An Imperial State at War: Britain from 1689 to 1815, Routledge, London and New York.

Thomas, Nicholas 1999, Possessions: Indigenous Art, Colonial Culture, Thames and Hudson, London. 
Passionate Histories

Wheeler, Roxann 2000, The Complexion of Race: Categories of Difference in Eighteenth-Century British Culture, University of Pennsylvania Press, Philadelphia. 